\title{
ОСОБЕННОСТИ МИНЕРАЛОГИЧЕСКОГО СОСТАВА ПЕСЧАНИКОВ БОЛЬШЕИНЗЕРСКОЙ СВИТЫ НИЖНЕГО РИФЕЯ (ЮЖНЫЙ УРАЛ) В СВЯЗИ С РУДООБРАЗОВАНИЕМ
}

\author{
А. Г. Султанова ${ }^{1,2}$, С. В. Мичурин ${ }^{1}$, А. А. Шарипова ${ }^{1}$ \\ ${ }^{1}$ Институт геологии УФИЦ РАН, г. Уфа \\ ${ }^{2}$ Баикирский государственный университет, г. Уфа \\ Поступила в редакцию 10 апреля 2019 г.
}

\begin{abstract}
Аннотация: в статье рассматриваются результаты изучения минералогических особенностей песчаников большеинзерской свиты нижнего рифея в Ямантауском антиклинории на Южном Урале. В его центральной части в песчаниках среди акиессорных минералов установлены рутил, титанит, ильменит, пирит, флюорит, ичикон, апатит, эпидот, актинолит, турмалин и золото, которое по химическому составу сходно с золотом из месторождения Улюк-Бар, располагающегося южнее исследованного участка. Находка золота и установленные содержания Аи до 0,5 2/m в песчаниках свить значительно севернее известных в районе коренных месторождений и рудопроявлений золота показывают перспективность исследованного участка на золотоносность. К минералогическим особенностям песчаников больиеинзерской свиты, которые могут быть связаны с золоторудным процессом, относятся появление в их составе флюорита и турмалина.
\end{abstract}

Ключевые слова: Ямантауский антиклинорий, нижний рифей, большеинзерская свита, минералогические особенности, золото, флюорит, турмалин.

\section{PECULIARITIES OF MINERALOGICAL COMPOSITION OF SANDSTONES OF THE BOLSHEINZER SUITE OF LOWER RIPHEAN (SOUTHERN URAL) IN CONNECTION WITH ORE FORMATION}

\begin{abstract}
: the article considers the results of the study of the mineralogical peculiarities of the sandstones of the Bolsheinzer suite of the Lower Riphean in the Yamantau anticlinorium in the Southern Urals. Rutile, titanite, ilmenite, pyrite, fluorite, zircon, apatite, epidote, actinolite, tourmaline and gold are found in sandstones in the central part of the Yamantau anticlinorium. Gold is chemically similar to gold from the Uluk-Bar deposit located south to the site studied. The prospects of the studied area for gold content are confirmed by the discovery of gold and the established Au content of up to $0.5 \mathrm{~g} / \mathrm{t}$ in the sandstones of the suite far to the north of the primary deposits and gold occurrences. The fluorite and tourmaline appearance in the sandstones of the Bolsheinzer suite shows the mineralogical peculiarities probably associated with the gold ore process
\end{abstract}

Key words: Yamantau anticlinorium, Lower Riphean, Bolsheinzer suite, mineralogical peculiarities, gold, fluorite, tourmaline.

Выходы отложений большеинзерской свиты нижнего рифея приурочены к Ямантаускому антиклинорию, который является составной частью Башкирского мегантиклинория на Южном Урале. В нем в составе нижнего рифея выделяют (снизу вверх) большеинзерскую, суранскую и юшинскую свиты [1], являющиеся возрастными аналогами соответственно айской, саткинской и бакальской свит типового разреза рифея. Породы свит простираются в субмеридиональном направлении и занимают обширную территорию. Большеинзерская свита подразделя- ется на нижнюю, среднюю и верхнюю подсвиты [1, 2]. Нижняя подсвита (мощность 220 м) представлена кварцевыми мелкозернистыми песчаниками с прослоями доломитов, известняков и углеродистоглинистых сланцев. Средняя подсвита (мощность 1150 м) сложена кварцевыми и полевошпаткварцевыми среднезернистыми песчаниками с прослоями $(0,1-0,2$ м) углеродисто-глинистых сланцев, кварцевых алевролитов и мелкогалечных конгломератов. Верхняя подсвита (мощность 780 м) представлена переслаиванием кварцевых песчаников, 
доломитов и углеродисто-глинистых сланцев.

Отложения большеинзерской свиты вмещают месторождение Улюк-Бар и рудопроявления Кургашлинское и Рамеева жила золото-кварцевого малосульфидного типа. Золоторудные объекты расположены вблизи субмеридионального Караташского регионального разлома и протягиваются цепочкой с юга на север, образуя Исмакаевскую рудную зону (рис. 1).

Несмотря на широкое распространение в Ямантауском антиклинории пород большеинзерской свиты и их значительную мощность, сведения по их минералогии скудны и имеются лишь единичные публикации $[1,3]$. Мы провели минералогическое изучение шлиховых проб из ручьев Бзяк и Безымянный, дренирующих отложения большеинзерской свиты, а также проб-протолочек коренных пород этой свиты, отобранных с поверхности и в обнажениях в районе д. Бзяк (рис. 1). Целью исследований являлось установление минералогического состава отложений, а также оценка их золотоносности.

Ручей Безымянный протекает примерно в 14-15 км севернее д. Исмакаево в районе д. Бзяк, который ранее [5] был отнесен к перспективным участкам в отношении золото-сульфидно-кварцевого оруденения. Вблизи от д. Бзяк берет свое начало одноименный ручей, впадающий в реку Бол. Авзян в 2-3 км севернее д. Исмакаево. Южнее этой деревни в долине p. Бол. Авзян известны Кургашлинская, Большой Ключ, Надеждинская (рис. 1) и другие золотоносные россыпи, за время эксплуатации которых добыто свыше 2 тонн золота.

\section{Методика исследований}

Минералогический анализ шлиховых проб проводился по стандартным методикам [6] и включал выделение различных фракций с последующим взвешиванием. Минералы определялись под бинокулярным микроскопом, а их процентное соотношение - рентгенофазовым анализом. Вес просеянных (-5 мм) проб составлял около 20-25 кг. Промывка проводилась в лотках до «серого» шлиха. Вес промытого шлиха составлял около 0,4-0,5 кг, который делили на две части - для минералогического анализа и для геохимического изучения. Рентгенофазовый анализ проводился на дифрактометре ДРОН-4 (аналитик Г. С. Ситдикова, ИГ УФИЦ РАН). Съёмка выполнялась в $\mathrm{Cu}$ К $\alpha$ излучении с шагом $0,02^{\circ}$ и временем счета, равным 10 с. Для расчетов использовалась длина волны К $\alpha 1=1,54060 \AA$, полученная при напряжении и токе на рентгеновской трубке 40 кВ и 40 мА, соответственно. Навеска образцов составляла 100-1000 мг.

Определение $\mathrm{Au}$ и $\mathrm{Ag}$ проводилось с экстракционным концентрированием дифинилтиомочевиной в пробах навеской 10 г атомно-абсорбционным анализом на спектрофотометре Спектр-5 (аналитик Н. Г. Христофорова, ИГ УФИЦ РАН). Предел обнаружения при измерении $\mathrm{Au}$ составлял 0,01 мкг/мл, $\mathrm{Ag}-0,001$ мкг/мл.
Определение химического состава золота выполнялось на растровом электронном микроскопе JEOL JSM 7100F (аналитик Г. С. Ситдикова, ИГ УФИЦ РАН), совмещенной с энергодисперсионной системой количественного анализа INCA ENERGY, в безэталонном режиме с нормализацией к $100 \%$, при ускоряющем напряжении $10 \mathrm{\kappa B}$, расстоянии между поверхностью образца и детектором 10 мм и диаметром лазерного пучка около 10 мкм. Вакуумирование образца $\left(5 \cdot 10^{-3} \mathrm{~Pa}\right)$ производилось в течение 20 мин.

\section{Обсуждение результатов}

При минералогическом изучении в тяжелой фракции пробы из руч. Бзяк (М-1001) определены рутил, пирит, циркон, флюорит, апатит, эпидот, актинолит, ильменит. В тяжелой фракции пробы из руч. Безымянный (М-1002) - рутил, пирит, циркон, флюорит. Описание минералов выполнено ранее [7]. По результатам рентгенофазового анализа в валовом составе шлиховых проб определены следующие минералы: кварц, мусковит, клинохлор, каолинит, гетит, титанит, рутил, ортоклаз, анортит (табл. 1). Как видно из приведенного описания, в результатах изучения двумя методами отмечается некоторое расхождение, связанное с отсутствием в данных рентгенофазового анализа циркона, флюорита, пирита в обеих пробах и апатита, ильменита, эпидота, актинолита в пробе из руч. Бзяк, что объясняется их незначительным содержанием $(\leq 0,1 \%)$.

В пробе-протолочке (М-1007) из коренных пород большеинзерской свиты в районе д. Бзяк по результатам рентгенофазового анализа установлен тот же состав минералов, что и в шлиховых пробах. Это говорит о том, что установленные минералы в целом отражают минеральный состав песчаников свиты.

Интересно и важно отметить в минералогическом составе изученных шлиховых проб прозрачные и полупрозрачные зерна флюорита неправильной формы зеленого и темно-зеленого цветов. Их размер в пробе М-1001 колеблется от 0,12x0,16 до 0,21х0,28 мм, в пробе М-1002 составляет 0,23х0,37 мм. Для отложений большеинзерской свиты это необычные находки, поскольку при детальном минералогическом изучении коренных пород стратотипического разреза свиты на р. Бол. Инзер флюорит в них не установлен $[1,3]$. Возможно, в изученные нами шлиховые пробы флюорит попал в результате размыва пород суранской свиты, располагающихся стратиграфически выше большеинзерских песчаников и вмещающих флюоритовые проявления и известное Суранское месторождение флюоритов, которое размещается в 56 и 12-14 км на север от точек отбора проб из ручьев Безымянный и Бзяк соответственно. Однако это маловероятно, поскольку флюорит впервые установлен нами и в коренных породах большеинзерской свиты - в пробах-протолочках песчаников (пробы М-549. М-551, М-568, М-571), отобранных в районе д. Бзяк. Флюорит здесь двух разновидностей: 

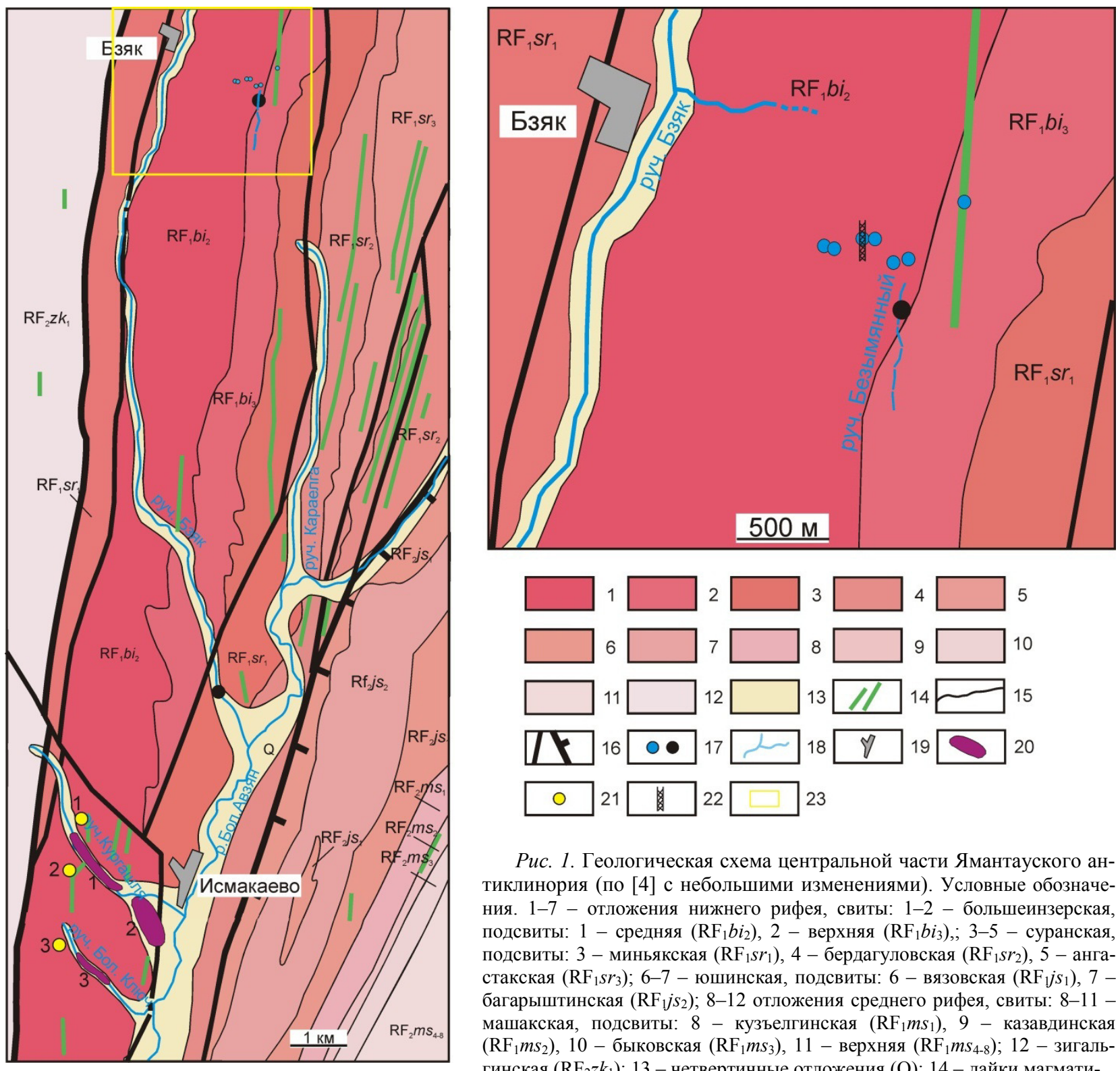

Puc. 1. Геологическая схема центральной части Ямантауского антиклинория (по [4] с небольшими изменениями). Условные обозначения. 1-7 - отложения нижнего рифея, свиты: 1-2 - большеинзерская, подсвиты: 1 - средняя $\left(\mathrm{RF}_{1} b i_{2}\right), 2$ - верхняя $\left(\mathrm{RF}_{1} b i_{3}\right) ; 3$ - 3 - суранская, подсвиты: 3 - миньякская $\left(\mathrm{RF}_{1} s r_{1}\right), 4$ - бердагуловская $\left(\mathrm{RF}_{1} s r_{2}\right), 5$ - ангастакская $\left(\mathrm{RF}_{1} s r_{3}\right)$; 6-7 - юшинская, подсвиты: 6 - вязовская $\left(\mathrm{RF}_{1} j s_{1}\right), 7$ багарыштинская $\left(\mathrm{RF}_{1} j s_{2}\right) ; 8-12$ отложения среднего рифея, свиты: 8-11 машакская, подсвиты: 8 - кузъелгинская $\left(\mathrm{RF}_{1} m s_{1}\right), 9$ - казавдинская $\left(\mathrm{RF}_{1} m s_{2}\right), 10$ - быковская $\left(\mathrm{RF}_{1} m s_{3}\right), 11$ - верхняя $\left(\mathrm{RF}_{1} m s_{4-8}\right) ; 12$ - зигальгинская $\left(\mathrm{RF}_{2} z k_{1}\right) ; 13$ - четвертичные отложения $(\mathrm{Q}) ; 14$ - дайки магматических пород; 15 - границы свит; 16 - тектонические нарушения разного порядка; 17 - точки отбора проб: синие - коренных пород, черные - шлиховых проб; 18 - реки и ручьи; 19 - населенные пункты; 20 - золотоносные россыпи: 1 - Кургашлинская; 2 - Надеждинская; 3 - Большой Ключ; 21 - рудопроявления и месторождение коренного золота Исмакаевской рудной зоны (1 Кургашлинское, 2 - Улюк-Бар, 3 - Рамеева жила); 22 - кварцевая жила; 23 - границы исследуемого участка.

Таблица 1

Минералогический состав шлиховых проб из ручьев Бзяк и Безымянный и пробы-протолочки из песчаника большеинзерской свиты в районе д. Бзяк по результатам рентгенофазового анализа

\begin{tabular}{|c|c|c|c|}
\hline \multirow{2}{*}{ Минерал } & \multicolumn{3}{|c|}{ Содержание, (\%) } \\
\cline { 2 - 4 } & $\begin{array}{c}\text { М-1001 } \\
\text { (руч. Бзяк) }\end{array}$ & $\begin{array}{c}\text { М-1002 } \\
\text { (руч. Безымянный) }\end{array}$ & $\begin{array}{c}\text { М-1007 } \\
\text { (проба-протолочка) }\end{array}$ \\
\hline Кварц & $88,0-93,0$ & $88,0-93,0$ & $87,0-92,0$ \\
\hline Мусковит & $0,8-1,3$ & $0,9-1,1$ & $0,3-0,7$ \\
\hline Клинохлор & $0,5-1,0$ & $0,6-0,9$ & $0,4-0,8$ \\
\hline Каолинит & $0,9-1,3$ & $0,8-2,1$ & $1,5-2,0$ \\
\hline Гётит & $0,5-1,0$ & $0,7-1,0$ & $0,1-0,4$ \\
\hline Титанит & $1,4-1,9$ & $0,4-0,8$ & $0,2-0,6$ \\
\hline Рутил & $0,4-0,8$ & $0,1-0,5$ & $0,1-0,6$ \\
\hline Ортоклаз & $1,0-1,5$ & $1,3-1,7$ & $0,9-1,4$ \\
\hline Анортит & $2,0-2,5$ & $1,5-1,9$ & $1,0-1,5$ \\
\hline
\end{tabular}


1) прозрачные зерна неправильной формы с раковистым изломом, зеленоватым оттенком и стеклянным блеском размером до $0,5 \times 0,8$ мм; 2) зональные обломки кристаллов с постепенным переходом от полупрозрачного с фиолетовым оттенком до фиолетово-черного цвета размером до 0,2х0,4 мм. Обработка плавиковой кислотой при температуре 140 $150^{\circ} \mathrm{C}$ в течение 1 часа не привела к растворению зерен, из чего можно заключить, что они не относятся к минералам силикатной группы и по всем минералогическим признакам соответствуют флюориту.

Генезис флюорита в песчаниках большеинзерской свиты, отобранных в районе д. Бзяк, вероятнее всего, гидротермальный, поскольку здесь же в тяжелой фракции пробы М-1002 из руч. Безымянный найдена пластинка золота, размером 0,10x0,12 мм. Поверхность золота ямчатая и слабо окатанная (рис. 2). Состав золота в (мас. \%): $\mathrm{Au}-84,25-95,92$ (ср. 89,21, $\mathrm{n}=10), \mathrm{Ag}-0,00-9,78$ (ср. 3,36) (табл. 2), $\mathrm{Au} / \mathrm{Ag}$ отношение в среднем равно 27,3. Это значение близко к отношению $\mathrm{Au} / \mathrm{Ag}$ в золоте из коры выветривания месторождения Улюк-Бар Исмакаевской рудной зоны, в котором оно равно 27-28 [8].

В составе золота отмечается примесь Рt до 1,54 и $\mathrm{Rh}$ до 0,36 мас. \% (табл. 2). Ранее примеси $\mathrm{Pt}$ до 3,1, $\mathrm{Pd}$ до 0,79 и $\mathrm{Rh}$ до 0,28 мас. \% выявлены в золотинах
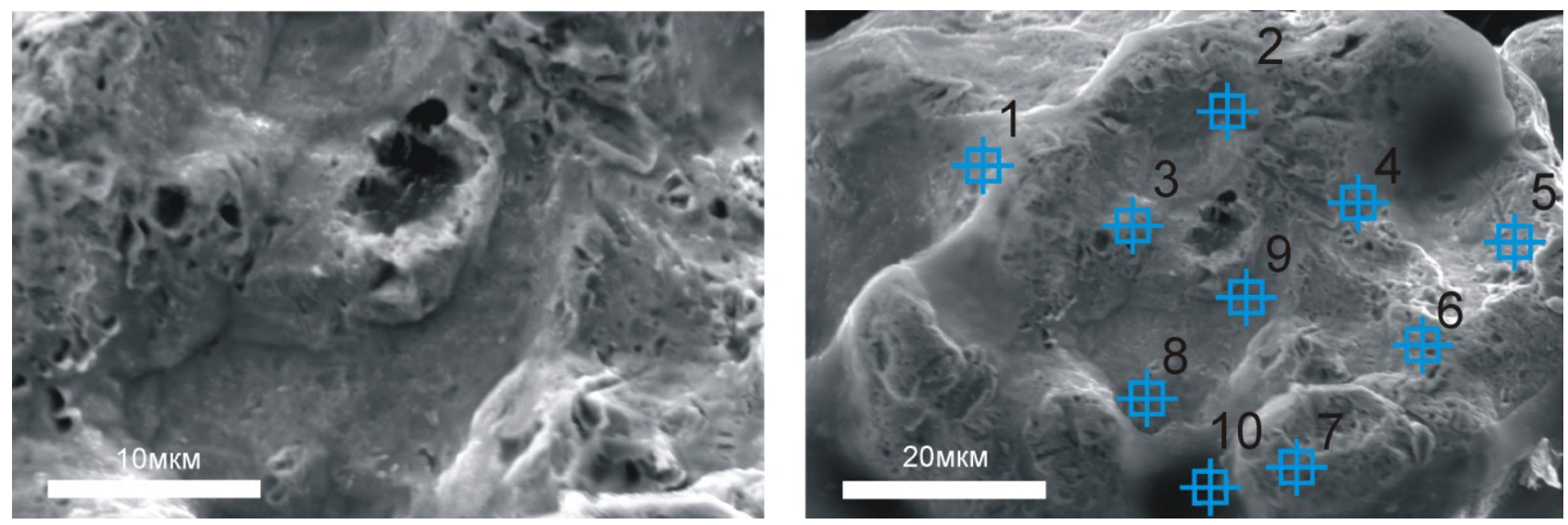

Puc. 2. Поверхность золота из руч. Безымянный и точки энергодисперсионного анализа.

Таблица 2

Химический состав золота по данным изучения на растровом электронном микроскопе (мас.\%)

\begin{tabular}{|c|c|c|c|c|c|c|c|c|c|c|}
\hline Элемент & $\mathrm{T}-1$ & $\mathrm{~T}-2$ & $\mathrm{~T}-3$ & $\mathrm{~T}-4$ & $\mathrm{~T}-5$ & T-6 & $\mathrm{T}-7$ & $\mathrm{~T}-8$ & T-9 & $\mathrm{T}-10$ \\
\hline $\mathrm{S}$ & 0,41 & 0,40 & $<\Pi \mathrm{O}$ & 1,35 & 1,48 & 1,86 & $<\Pi$ & 0,83 & 1,64 & $<\Pi \mathrm{O}$ \\
\hline $\mathrm{Ti}$ & $<\Pi \mathrm{C}$ & 0,11 & $<\Pi O$ & 0,03 & $<\Pi$ & 0,17 & $<\Pi \mathrm{O}$ & 0,05 & 0,13 & $<\Pi O$ \\
\hline $\mathrm{Fe}$ & 0,27 & 0,56 & 0,19 & 0,30 & $<\Pi \mathrm{O}$ & 1,08 & $<\Pi \mathrm{O}$ & 0,30 & 0,07 & 0,14 \\
\hline $\mathrm{Co}$ & 0,10 & 0,05 & 0,04 & $<\Pi \mathrm{O}$ & $<\Pi \mathrm{O}$ & $<\Pi O$ & $<\Pi О$ & $<\Pi \mathrm{O}$ & 0,08 & 0,16 \\
\hline $\mathrm{Ni}$ & $<\Pi \mathrm{C}$ & 0,05 & 0,09 & 0,04 & 0,26 & 0,42 & $<\Pi О$ & 0,14 & 0,03 & $<\Pi O$ \\
\hline $\mathrm{Cu}$ & 0,65 & 0,14 & 0,15 & 0,25 & $\mathbf{0 , 4 7}$ & $\mathbf{0 , 3 1}$ & $\mathbf{0 , 9 7}$ & $<\Pi O$ & 0,56 & 0,99 \\
\hline As & 0,56 & 0,44 & 0,10 & $<\Pi О$ & 0,51 & $<\Pi О$ & $<\Pi О$ & 0,21 & 0,49 & $<\Pi O$ \\
\hline $\mathrm{Se}$ & 0,93 & 0,50 & 0,20 & $\mathbf{0 , 8 7}$ & $<\Pi O$ & 0,07 & $<\Pi О$ & $<\Pi O$ & 0,22 & $<\Pi О$ \\
\hline Mo & $<\Pi \mathrm{C}$ & $<\Pi О$ & 2,69 & $<\Pi O$ & $<\Pi \mathrm{O}$ & $<\Pi \mathrm{O}$ & 1,20 & $<\Pi О$ & $<\Pi O$ & $<\Pi O$ \\
\hline $\mathrm{Rh}$ & $<\Pi \mathrm{C}$ & $<\Pi O$ & $<\Pi \mathrm{O}$ & $<\Pi \mathrm{O}$ & $<\Pi O$ & 0,31 & $<\Pi O$ & $<\Pi \mathrm{O}$ & 0,36 & $<\Pi O$ \\
\hline $\mathrm{Ag}$ & 3,41 & $<\Pi O$ & 4,75 & 9,78 & 5,21 & 1,17 & $<\Pi \mathrm{O}$ & 2,48 & 5,55 & 1,31 \\
\hline $\mathrm{Sn}$ & 0,16 & $<\Pi \mathrm{O}$ & 0,58 & 0,45 & $<\Pi \mathrm{O}$ & $<\Pi \mathrm{O}$ & 0,52 & $<\Pi \mathrm{O}$ & 0,42 & $<\Pi \mathrm{O}$ \\
\hline $\mathrm{Sb}$ & 0,14 & $<\Pi О$ & 0,30 & $<\Pi \mathrm{O}$ & $<\Pi \mathrm{O}$ & 1,12 & 0,74 & 0,08 & $\mathbf{0 , 5 3}$ & $<\Pi \mathrm{O}$ \\
\hline $\mathrm{Te}$ & 0,27 & $<\Pi \mathrm{O}$ & 0,28 & 0,19 & $<\Pi \mathrm{O}$ & 0,76 & 0,99 & 0,47 & 0,14 & $<\Pi$ $<$ \\
\hline $\mathrm{Ta}$ & 0,39 & $<\Pi O$ & $<\Pi \mathrm{C}$ & 0,55 & $<\Pi \mathrm{O}$ & 0,72 & $<\Pi \mathrm{O}$ & $<\Pi \mathrm{O}$ & 0,14 & $<\Pi \mathrm{O}$ \\
\hline $\mathrm{W}$ & $<\Pi$ & $<\Pi \mathrm{O}$ & $<\Pi \mathrm{O}$ & 0,68 & $<\Pi \mathrm{O}$ & 0,55 & 0,42 & 0,22 & 0,20 & 0,65 \\
\hline $\mathrm{Pt}$ & $<\Pi$ & $<\Pi О$ & 1,54 & $<\Pi \mathrm{O}$ & 0,87 & 0,78 & 2,63 & 1,45 & 1,48 & $<\Pi O$ \\
\hline $\mathrm{Au}$ & 89,46 & 86,85 & 84,25 & 85,51 & 88,16 & 90,67 & 92,54 & 92,90 & 85,91 & 95,92 \\
\hline $\mathrm{Hg}$ & 2,44 & 4,13 & 4,85 & $<\Pi \mathrm{O}$ & 1,98 & $<\Pi \mathrm{O}$ & $<\Pi \mathrm{O}$ & $<\Pi \mathrm{O}$ & 1,09 & 0,83 \\
\hline $\mathrm{Bi}$ & 0,82 & $<\Pi О$ & $<\Pi$ & $<\Pi \mathrm{O}$ & 1,06 & $<\Pi O$ & $<\Pi \mathrm{O}$ & $\mathbf{0 , 8 8}$ & 0,97 & $<\Pi O$ \\
\hline$\sum$ & 100 & 100 & 100 & 100 & 100 & 100 & 100 & 100 & 100 & 100 \\
\hline
\end{tabular}

Примечание: Т-1 - Т-10 - точки энергодисперсионного анализа, показанные на рис. 1. В составе золота определялся Рd,

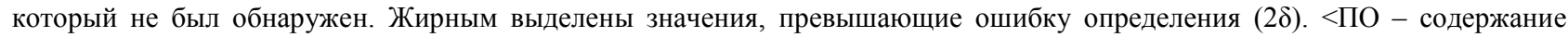
элемента ниже предела обнаружения. 
месторождения Улюк-Бар С. Г. Ковалевым и И. В. Высоцким [9], которые считают, что это указывает на привнос $\mathrm{Au}$ металлоносными флюидами мантийного генезиса. Изредка в составе золота из руч. Безымянный фиксируются содержания (в мас. \%): Ті (до 0,17), Мо (до 2,69), Та (до 0,72), Ві (до $0,97)$. Учитывая положительную связь Bi c As и $\mathrm{S}$, с коэффициентами корреляции 0,73 и 0,40 соответственно, можно предположить, что Ві присутствует в микровключениях арсенопирита на поверхности золота. В свою очередь $\mathrm{S}$ обнаруживает связь с $\mathrm{Fe}$ $\left(K_{\text {корр }}=0,42\right)$ и $\mathrm{Ni}(0,59)$, что, вероятно, указывает на присутствие на поверхности золота микровключений пирита и герсдорфита. Отметим при этом, что ранее [10] в арсенопирите, пирите, пирротине, герсдорфите и галените месторождения Улюк-Бар установлена постоянная примесь Bi.

Следует отметить высокое содержание $\mathrm{Hg}$ (до 4,85 мас. \%) в золоте из руч. Безымянный и, вероятно, оно является ртутистым. Кроме того, в его составе установлены примеси (в мас. \%): Se (до 0,93),
$\mathrm{Sb}$ (до 1,12), Sn (до 0,58), Те (до 0,99). Следует отметить, что ранее в золотинах месторождения Улюк-Бар зафиксированы незначительные примеси ртути до 0,1 мас. \% [11].

Обращает внимание присутствие примеси $\mathrm{Cu}$ (среднее содержание 0,56 мас. \%) в золоте из руч. Безымянный, что не характерно для золота Исмакаевской рудной зоны [9]. Сu является единственным элементом, который имеет положительную корреляцию с содержанием $\mathrm{Au}$ в найденной золотине, с коэффициентом 0,54 .

Для сравнения мы проанализировали состав золота из месторождения Улюк-Бар. Был взят образец песчаника большеинзерской свиты (скв. №7852, гл. 673 м) с вкрапленностью арсенопирита и пирита, в которых отмечаются выделения золота (рис. 3). В его составе установлено в (мас. \%): $\mathrm{Au}-$ 79,30-85,65 (ср. 83,04, n = 20) и Ag 12,78-17,39 (ср. $14,00)$. Средняя пробность составляет 830. $\mathrm{Au} / \mathrm{Ag}$ отношение колеблется от 4,7 до 6,45 при среднем значении 5,97 (табл. 3).
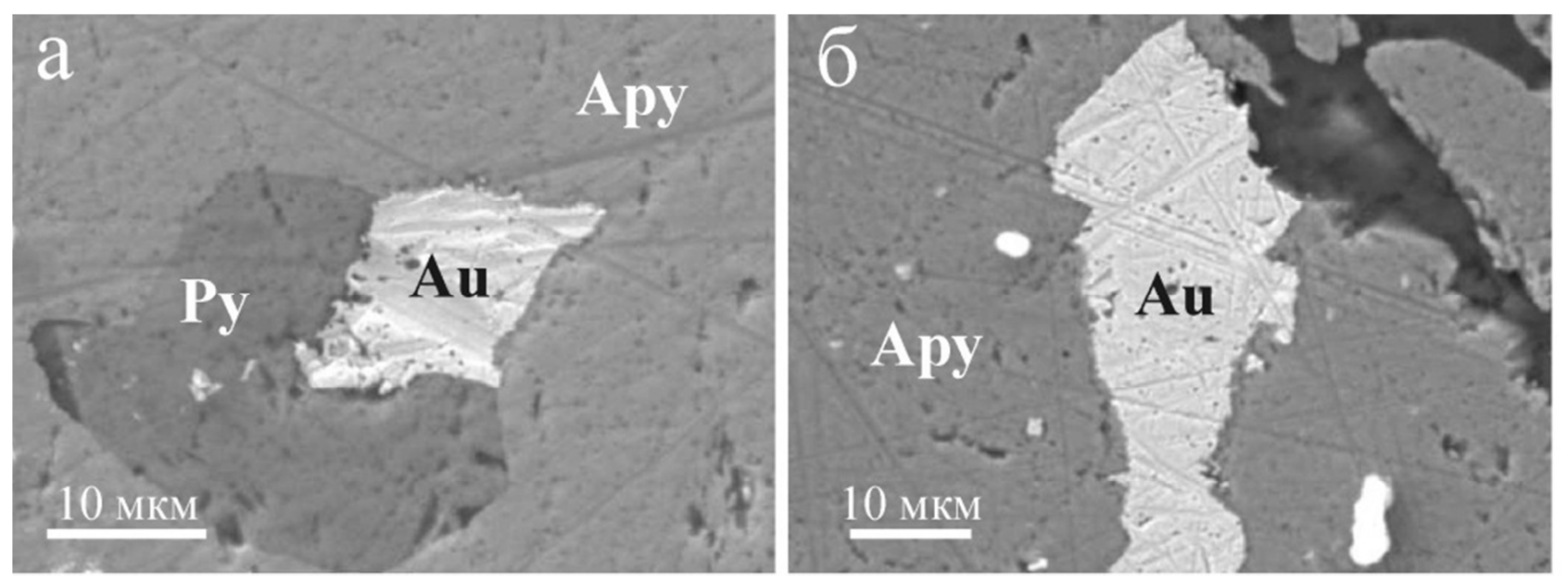

Puc. 3. Золото в пирите (Ру) и арсенопирите (Ару) в песчанике из месторождения Улюк-Бар

Таблица 3

Состав золота (мас. \%) из месторождения Улюк-Бар

\begin{tabular}{|c|c|c|c|c|c|c|c|c|c|c|c|c|}
\hline № & $\mathrm{Au}$ & $\mathrm{Ag}$ & $S$ & $\mathrm{Fe}$ & Co & $\mathrm{Ni}$ & $\mathrm{Cu}$ & As & $\mathrm{Te}$ & Mo & $\mathrm{Hg}$ & $\mathrm{Pb}$ \\
\hline 1 & 2 & 3 & 4 & 5 & 6 & 7 & 8 & 9 & 10 & 11 & 12 & 13 \\
\hline 1 & 83,77 & 13,36 & - & 0,18 & $<\Pi О$ & 0,20 & - & 0,45 & $\mathbf{0 , 3 3}$ & 1,70 & - & $<\Pi О$ \\
\hline 2 & 83,34 & 12,96 & - & $\mathbf{0 , 1 7}$ & $<\Pi \mathrm{O}$ & $<\Pi О$ & - & 2,16 & $<\Pi O$ & 1,37 & - & $<\Pi \mathrm{O}$ \\
\hline 3 & 82,77 & 13,92 & - & $\mathbf{0 , 5 0}$ & $<\Pi О$ & $<\Pi$ & - & $\mathbf{0 , 3 5}$ & $<\Pi О$ & 2,45 & - & $<\Pi О$ \\
\hline 4 & 84,99 & 14,21 & - & $\mathbf{0 , 3 0}$ & $<\Pi O$ & 0,13 & $<\Pi О$ & - & $\begin{array}{l}\mathbf{0 , 3 7} \\
\end{array}$ & - & - & - \\
\hline 5 & 84,94 & 14,27 & - & $\mathbf{0 , 3 0}$ & $<\Pi О$ & 0,13 & $<\Pi$ & - & $\mathbf{0 , 3 7}$ & - & 1,82 & - \\
\hline 6 & 85,65 & 13,27 & - & $\mathbf{0 , 7 0}$ & - & - & - & - & $\mathbf{0 , 3 8}$ & $<\Pi О$ & 2,86 & 1,01 \\
\hline 7 & 83,05 & 13,07 & - & $\mathbf{0 , 5 8}$ & - & $<\Pi \mathrm{O}$ & 0,19 & $<\Pi О$ & 0,29 & 2,82 & $<\Pi$ & $<\Pi O$ \\
\hline 8 & 81,55 & 13,86 & - & 0,54 & 0,09 & $<\Pi О$ & - & $\mathbf{0 , 9 5}$ & $<\Pi$ & 3,00 & - & $<\Pi O$ \\
\hline 9 & 83,95 & 13,87 & - & 0,23 & $<\Pi О$ & $<\Pi О$ & - & 0,29 & $<\Pi$ & 1,65 & - & $<\Pi \mathrm{O}$ \\
\hline 10 & 81,39 & 13,40 & - & 0,74 & $<\Pi О$ & $<\Pi$ & - & 1,12 & $<\Pi О$ & 3,36 & - & $<\Pi О$ \\
\hline 11 & 83,11 & 13,36 & - & 0,94 & $<\Pi \mathrm{O}$ & $<\Pi О$ & - & $\mathbf{0 , 5 3}$ & $\mathbf{0 , 1 7}$ & 1,89 & - & $<\Pi O$ \\
\hline 12 & 82,21 & 17,39 & $<\Pi О$ & 0,22 & $<\Pi \mathrm{O}$ & $<\Pi \mathrm{O}$ & $<\Pi$ & $\mathbf{0 , 1 8}$ & - & - & - & - \\
\hline 13 & 81,99 & 17,22 & $<\Pi$ & 0,47 & $<\Pi О$ & $<\Pi О$ & $<\Pi$ & $\mathbf{0 , 3 2}$ & - & - & - & - \\
\hline 14 & 79,30 & 15,10 & 1,06 & 2,88 & $<\Pi \mathrm{O}$ & $<\Pi \mathrm{O}$ & $<\Pi$ & 1,65 & - & - & - & - \\
\hline 15 & 84,99 & 14,21 & - & $\mathbf{0 , 3 0}$ & $<\Pi О$ & $\mathbf{0 , 1 3}$ & - & - & $\mathbf{0 , 3 7}$ & - & - & - \\
\hline 16 & 82,09 & 13,81 & - & $\mathbf{0 , 5 0}$ & $<\Pi \mathrm{O}$ & $<\Pi \mathrm{O}$ & - & $\mathbf{0 , 3 5}$ & $<\Pi О$ & 2,43 & - & $<\Pi \mathrm{O}$ \\
\hline
\end{tabular}


Продолжение табл. 3

\begin{tabular}{|c|c|c|c|c|c|c|c|c|c|c|c|c|}
\hline 1 & 2 & 3 & 4 & 5 & 6 & 7 & 8 & 9 & 10 & 11 & 12 & 13 \\
\hline 17 & $\mathbf{8 2 , 8 8}$ & $\mathbf{1 2 , 8 9}$ & - & $\mathbf{0 , 1 7}$ & $<\Pi$ & $<\Pi$ & - & $\mathbf{2 , 1 5}$ & $<\Pi О$ & $\mathbf{1 , 3 6}$ & - & $<\Pi О$ \\
\hline 18 & $\mathbf{8 2 , 9 2}$ & $\mathbf{1 3 , 2 2}$ & - & $\mathbf{0 , 1 8}$ & $<\Pi О$ & $\mathbf{0 , 2}$ & - & $\mathbf{0 , 4 5}$ & $\mathbf{0 , 3 3}$ & $\mathbf{1 , 6 8}$ & - & $<\Pi О$ \\
\hline 19 & $\mathbf{8 3 , 4 1}$ & $\mathbf{1 4 , 0 1}$ & - & $\mathbf{0 , 2 9}$ & $<\Pi О$ & $\mathbf{0 , 1 3}$ & $<\Pi О$ & - & $\mathbf{0 , 3 6}$ & - & $\mathbf{1 , 7 9}$ & - \\
\hline 20 & $\mathbf{8 2 , 4 7}$ & $\mathbf{1 2 , 7 8}$ & - & $\mathbf{0 , 6 7}$ & - & - & - & - & $\mathbf{0 , 3 7}$ & $<\Pi О$ & $\mathbf{2 , 7 5}$ & $\mathbf{0 , 9 7}$ \\
\hline
\end{tabular}

Примечание: <ПО - содержание элемента ниже предела обнаружения. Прочерк - нет данных. Жирным выделены значения, превышающие ошибку определения (2ס).

В золоте из месторождения Улюк-Бар, также как и в золоте из ручья Безымянный, установлены примеси (мас. \%): Мо (до 3,36), $\mathrm{Hg}$ (до 2,86), Fe (до 2,8), As $(0,18-2,16)$, Те (до 0,38), S (до 1,06), изредка фиксируются незначительные содержания $\mathrm{Ni}, \mathrm{Co}, \mathrm{Cu}$ до 0,1 0,2 мас. \%. В нем отсутствуют Pt, Вi и в одном анализе зафиксировано сравнительно высокое содержание $\mathrm{Pb} 1,01$ мас. \%. Таким образом, найденная пластинка золота в аллювиальных отложениях ручья Безымянный по химическому составу в целом сходна с золотом из месторождения Улюк-Бар. Сама находка золота значительно севернее известных в районе коренных месторождений и рудопроявлений золота показывает перспективность исследованного участка в районе д. Бзяк на золотоносность.

Данный вывод подтверждают результаты атомноабсорбционного анализа, которые показывают что в песчаниках этого участка на контакте с кварцевой жилой, мощностью около 8-9 м, содержания $\mathrm{Au}$ и $\mathrm{Ag}$ составляют приблизительно 0,5 г/т (табл. 4). Кроме того, ранее в породах этого участка был обнаружен золотосодержащий кобальтин [5]. Из минералогических особенностей здесь следует отметить присутствие в песчаниках (проба М-1007) обломков призматических кристаллов турмалина светло-розового цвета размером от $0,04 \times 0,07$ мм до $0,07 \times 0,18$ мм. Турмалин установлен только в этой пробе, имеющей максимальное содержание Au в проанализированной выборке, и, вероятнее всего, его образование связано с золоторудным процессом.

Таблица 4

Содержание Aи и $\mathrm{Ag}(2 / \mathrm{m})$ в песчаниках большеинзерской свиты из района д. Бзяк по результатам атомно-абсорбционного анализа

\begin{tabular}{|c|l|c|c|}
\hline $\begin{array}{c}\text { № } \\
\text { образца }\end{array}$ & \multicolumn{1}{|}{ Характеристика образца } & $\mathrm{Ag}$ & $\mathrm{Au}$ \\
\hline 1001 & шлих, руч. Бзяк & 0,25 & 0,13 \\
\hline 1002 & шлих, руч. Безымянный & 0,15 & $<0,1$ \\
\hline 1004 & песчаник & 0,16 & $<0,1$ \\
\hline 1005 & песчаник & 0,20 & 0,11 \\
\hline 1006 & песчаник & 0,43 & 0,46 \\
\hline 1007 & песчаник на контакте с & 0,56 & 0,48 \\
\hline $1007 / 1$ & кварцевая жила & 0,60 & 0,20 \\
\hline
\end{tabular}

\section{Выводы}

1. В минералогическом составе песчаников большеинзерской свиты нижнего рифея установлены кварц (преобладает), полевые шпаты, клинохлор, каолинит, мусковит и акцессорные минералы. К последним относятся рутил, титанит, ильменит, пирит, флюорит, циркон, апатит, эпидот, актинолит, турмалин и золото. Преобладающим среди них минералом в шлиховых пробах является титанит (около $1 \%$ ).

2. В аллювиальных отложениях ручья Безымянный найдена пластинка золота. По химическому составу оно сходно с золотом из месторождения Улюк-Бар Исмакаевской рудной зоны. Находка золота и установленные содержания $\mathrm{Au}$ до 0,5 г/т в песчаниках свиты значительно севернее известных в районе коренных месторождений и рудопроявлений золота показывают перспективность исследованного участка в районе д. Бзяк на золотоносность.

3. К минералогическим особенностям песчаников большеинзерской свиты, которые могут быть связаны с золоторудным процессом, относятся появление в их составе флюорита и турмалина. Первый из них имеет более широкое распространение по сравнению со вторым, отражая, по-видимому, общую гидротермальную проработку золотоносного участка. Образование турмалина, вероятно, непосредственно связано с деятельностью золотоносных флюидов, поскольку он встречается локально в наиболее обогащенных $\mathrm{Au}$ породах участка.

Исследования выполнены в рамках темы № 02522016-0005 государственного задания ИГ УФИЦ РАН.

\section{ЛИТЕРАТУРА}

1. Козлов, В. И. Нижний рифей Южного Урала / В. И. Козлов [и др.]. - М.: Наука, 1989. - 208 с.

2. Маслов, А. В. Осадочные последовательности рифея типовой местности (ретроспективный обзор седиментологических, палеогеографических, литолого-минералогических и петрогеохимических исследований) / А. В. Маслов, Э. З. Гареев, М. Т. Крупенин. - Уфа: Принт, 1998. - 225 с.

3. Сергеева, Н. Д. Сопоставление айской и большеинзерской свит нижнего рифея Башкирского мегантиклинория Южного Урала по акцессорным минералам / Н. Д. Сергеева // Верхний докембрий и палеозой Южного Урала (стратиграфия и литология): Сборник научных трудов. - Уфа: БФАН СССР, 1982. - С. 20-26.

4. Ларионов, Н. Н. Государственная геологическая карта Российской Федерации. 1:200 000. Южно-Уральская сер. N40-XXII (Тукан) / Н. Н. Ларионов - СПб.: МПР РФ, 2003.

5. Мичурин, С. В.Генезис сульфатов и сульфидов в нижнерифейских отложениях Камско-Бельского авлакогена и Башкирского мегантиклинория / С. В. Мичурин, С. Г. Ковалев, В. М. Горожанин. - Уфа: ДизайнПолиграфСервис, 2009. - 192 c. 
6. Копченова, E. В. Минералогический анализ шлихов / Е. В. Копченова. - Москва: Изд-во геологической литературы, 1951. $-213 \mathrm{c}$.

7. Захарова, А. Г. Минералогические особенности большеинзерской свиты нижнего рифея (Южный Урал) по результатам шлихового опробования / А. Г. Захарова, С. В. Мичурин, А. А. Шарипова // Проблемы минералогии, петрографии и металлогении. Научные чтения памяти П.Н. Чирвинского: сб. науч. ст. ПГНИУ; ГИ УрО РАН. Пермь, 2019. - С. $37-44$.

8. Захарова, А. Г. Минералогические и геохимические особенности отложений бердагуловской подсвиты суранской свиты нижнего рифея по результатам шлихового опробования (Южный Урал) / А. Г. Захарова, С. В. Мичурин, А. А. Шарипова // Геология, полезные ископаемые и проблемы геоэкологии Башкортостана, Урала и сопредель-

Башкирский государственный университет, г. Уфа, Институт геологии Уфимский федеральный исследовательский иентр РАН, г. Уфа

Султанова Анна Геннадиевна, магистрант, младший научный сотрудник

E-mail: anna_zakharova.ig@mail.ru

Тел.: +7 (347) 2735145

Институт геологии Уфимский федеральный исследовательский центр $P A H$, г. Уфа

Мичурин Сергей Васильевич, кандидат геологоминералогических наук

E-mail: s_michurin@mail.ru

Тел.: +7(347) 2735145

Шарипова Айсылу Азатовна, младший научный сотрудник, E-mail:: aysyluazatovna@mail.ru

Тел.: +7(347) 2735145 ных территорий: Сборник статей 12-ой Межрегиональной научно-практической конференции, Уфа, 21-23 мая 2018 г. - Спб: Свое издательство, 2018. - С. 227-237.

9. Ковалев, С. Г. Геохимия золота западного склона Южного Урала / С. Г. Ковалев, И. В. Высоцкий // Геология и перспективы расширения сырьевой базы Башкортостана и сопредельных территорий. Мат-лы IV Респ. геол. конф. Уфа, 2001. - С. 134-140.

10. Ковалев, С. Г. Геохимическая специализация структурно-вещественных комплексов Башкирского мегантиклинория / С. Г Ковалев [и др.]. - Уфа: дизайнпресс, 2013.- 88 с.

11. Мичурин, С. В. Сульфидная минерализация, самородное золото и его геохимические связи в рифейских отложениях Авзянского рудного района (Южный Урал) / С. В. Мичурин [и др.] // Литосфера. - 2018. - Т. 18. - № 1. - С. 61-81.

Federal State Budgetary Educational Institution of Higher Education "Bashkir State University» (BSU), Ufa

Institute of Geology - Subdivision of the Ufa Federal Research Centre of the Russian Academy of Sciences, Ufa

Sultanova A. G., master student, junior researcher

E-mail: anna_zakharova.ig@mail.ru

Tel.: +7(347) 273-51-45

Institute of Geology - Subdivision of the Ufa Federal Research Centre of the Russian Academy of Sciences, Ufa

Michurin S. V., Candidate of Geological and Mineralogical Sciences

E-mail: s_michurin@mail.ru

Tel.: +7(347) 2735145

Sharipova A. A., junior researcher

E-mail: aysyluazatovna@mail.ru

Tel.:+7(347) 2735145 